\title{
Pedagogical Techniques Teachers Use to Bolster Extensive Reading Habits in Secondary Schools in Kenya
}

\author{
*Dr. Francis G. Mwangi Dr. Adelheid M. Bwire \\ Department of Educational Communication and Technology, Faculty of Education, Kenyatta \\ University. P.O. BOX 43844,Nairobi, Kenya. Zip Code: 00100
}

\begin{abstract}
This study addresses the issue of pedagogical techniques for extensive reading in secondary schools in Kenya at a time when concern is being expressed about declining reading habits in the institutions of learning. Learners nowadays have taken to social and mass media and rarely read anything extra outside the prescribed texts. Even the wide spread national examination malpractice witnessed recently could be traced to the decline in reading interest and poor reading habits among secondary school learners. Effective use of pedagogical extensive reading techniques can greatly improve learners' achievement in English and also enhance their reading habits. This study was prompted by the observed poor reading in English by secondary schools learners in Laikipia County in Kenya. Among some of the possible explanations for this scenario are that students in the County did not adequately read books extensively coupled with other determinants that influence their performance in English. The study investigated the pedagogical techniques used by teachers to bolster extensive and pleasure reading habits. The study was guided by The Schema Theory. The descriptive survey research design was used for this study. Fifteen secondary schools in Laikipia County were sampled by proportional stratified sampling technique in five subcounties across the county. Purposive sampling was used to sample 30 out of 80 (37.5\%) English language teachers. Simple random sampling was used to sample 327 students out of about 2670 students (12.24\%) in form 2 and 3 in the County. The research instruments used for data collection included: questionnaire for students, interview guides for teachers and documents analysis guide. The instruments were pilot tested to ensure validity and reliability in a co-educational secondary school in the neighbouring county that was not included in the study. The reliability of the questionnaire and interview guide was estimated using Cronbach's alpha coefficient which was 0.871 which met the recommended threshold of 0.7 and above. Analysis of data was done using descriptive statistics such as frequency, tables and percentages. Qualitative data were organized according to the study themes and presented descriptively on the basis of the study objectives. The analyzed data revealed various reading pedagogical techniques which included analysis of the title and the blurb before reading, formation of mental images while reading and writing book reviews after reading. Acute shortage of reading resources was a major hindrance to engagement in extensive reading in schools. The study recommended that schools should ground learners on reading techniques and also come up with strong extensive reading policy to promote independent reading.
\end{abstract}

Keywords: Pedagogical techniques, Bolster, Extensive reading, Reading habits

DOI: $10.7176 / \mathrm{JEP} / 11-6-23$

Publication date: February $29^{\text {th }} 2020$

\section{Introduction}

The performance of English language in Kenya in secondary schools has been declining each successive year (KNEC, 2014). There could be many causes of this scenario but one of them could be declining reading culture in our secondary schools. Reading mostly develops in the learners gradually and this is determined by social and academic background of the learners (West \& Schwerdt, 2012). The purpose for reading also determines what they read in terms of written materials they prefer. There are readers who choose to read to gather information, general knowledge and interest (Makenzi, 2009). Sentuwa (2004) asserts that reading is a very important learning skill that reinforces and dictates the success of other learning undertaking in classrooms. In the context of this study, reading is a complex, purposeful, sociocultural, cognitive and linguistic process in which readers simultaneously uses their knowledge of spoken and written language, their knowledge of the text, and the knowledge of their culture to construct meaning with the text.

In a survey conducted in the United States of America by the National Endowment for the Arts referred to as "Reading at Risk," it was established that nearly more than half of the American adults did not engage in reading books for enjoyment. It was also noted that statistics were worrying when it came to the American youth as their reading rates were found to be on the decline. It was established that the number of those people who engage in voluntary reading went down by 10 percent between 1982 and 2002 and currently the decline is worrying. Commeyras and Mazile (2011) citing a study in Botswana on independent and voluntary reading among primary school learners found that the rich oral African linguistic bond was the main challenge in developing a reading culture as it seemed to envelop the print culture. Yet according to Rosenber (2003) developing a reading culture in schools is the main strategy that can contribute to academic of excellence of learners and improve literacy levels. 
Ikerenge (2013) notes that Kenyan education system is squarely to blame for the alarming decline in reading culture among the school going youth. This is because of overemphasis on attainment of good academic grades at the expense of nurturing talents and skills amongst learners. This assertion is supported by Ngwiri (2014) who reiterates that young people do not have role models in developing their reading culture since the adults, who should be role models, just do not have the reading culture. He argues that Kenyans do not read and if they do then they read for examinations only. This has resulted in the education system churning out young graduates who can hardly engage themselves in intellectual discourse despite attaining exemplary grades in their academics. As a result of the poor reading habits in schools these young graduates can hardly maintain a logical flow of an argument in an academic forum (Ikerenge, 2013). Gicobi (2013) notes that some of the standard eight candidates of the year 2012 failed flat in writing compositions, a post-mortem report on the tests showed. So poor were their essays that language experts expressed concern over the candidates' preparedness to tackle English composition in Kenya certificate of primary education (KCPE). According to $2012 \mathrm{KCPE}$ examination report, some of the candidates could hardly write simple words correctly and serious first language (L 1) interference were equally noted as challenges faced by the candidates.

In Kenya, primary school teacher training emphasizes on pedagogical approaches of the four basic skills of reading, writing, listening and speaking as they are the pillars of language learning. The Kenya Institute of Curriculum Development (KICD) provides guidelines to practicing teachers on how to approach the teaching of the four language skills. These outlines should be followed throughout the primary course to ensure language development is achieved by learners at all levels. However, training of language teachers at Kenyan colleges and universities does not clearly place emphasis on reading as it is assumed by language teachers that secondary school learners leave primary schools having mastered reading skills. This grave assumption has led to decline in voluntary reading as they do not see any importance in engaging in what is not emphasized by their teachers. Education experts have openly criticized Kenya curriculum for being narrow in scope and being examination oriented rather than focusing on imparting practical knowledge and skills that will be of value to learners in the lifelong (Shiundu \& Omulando, 1992).

\section{Purpose of the Study}

The purpose of the study was to explore the pedagogical techniques that promote and sustain acquisition of extensive reading habits and how they influence learners' proficiency in extensive and pleasure reading in secondary schools in Laikipia County, Kenya.

\section{Theoretical and Conceptual Framework}

According to The Schema Theory, knowledge kept in the mind of a person is organized into units called schemata. The schema (plural schemata) is described as building blocks of cognition which is applied in the process of interpreting and comprehending sensory data picked up from both short and long term memory. Rumelhart (1980) states that schema can represent knowledge at several levels from ideologies to knowledge on morphology, syntax and semantics of a text. Finally, schemata are our knowledge that we possess from various sources and if the learners have limited exposure to reading materials then their schemata will be limited. From the Schema Theory the following conceptual framework emerged, which guided the study.

\section{Intervening variable}

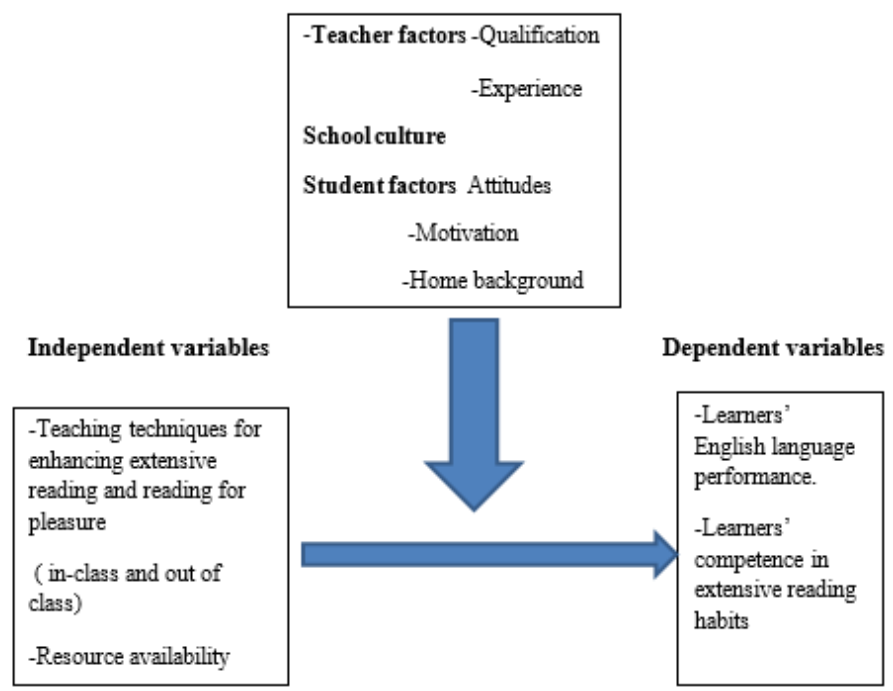

Figure 1: Relationship between independent, intervening and dependent variables of the study 
The framework shows the independent variables in this study as provision of books and other reading materials and teachers' pedagogical skills in influencing reading. These variables were investigated to establish whether they have any influence on learners' achievement in composition writing and learners' competence in extensive reading. The dependent variable was students' achievement in composition writing. Intervening variables are variables that may influence the independent variables in explaining the outcome of the study. The intervening variables in this study were teachers' factors that include teachers' qualifications, teachers' attitudes, students' attitudes and school environment. To account for these variables, the teachers who participated in the study were those who had a degree in education and were trained to teach reading English in secondary schools. They must have taught for at least two years.

\section{Methodology \\ Research Design}

The study utilized a descriptive survey research design. According to Fraenkel and Wallen (2003) surveys are cost effective and efficient when populations are large and their analyses are direct. The major purpose of this design is to describe the state of affairs as it exists (Kombo \& Tromp, (2009), Orodho, (2005). A descriptive survey design therefore, attempts to describe characteristics of subjects or phenomena, attitudes, opinions, preferences and perceptions of persons of interest to the researcher (Kombo \& Tromp, 2009, Mugenda \& Mugenda, 2003). Descriptive research was used to obtain information concerning pedagogical techniques that promote extensive reading habits in secondary schools. The research design helped in collecting a complete and possibly accurate data from the research subjects which was used for detailed analysis and which led to important recommendations that were made. The study was supplemented by views of qualitative data in form of respondents' views, comments and opinions on main themes the study had raised. The study also used descriptive statistical methods to analyze and present quantitative data. The study used qualitative method because it involves analysis and presentation of data in forms of descriptive nature (data obtained are expressed in words). For qualitative data, the researcher used semi-structured interviews with English language teachers. Quantitative method of data collection was employed because the study used descriptive statistical methods to present and analyze study data in frequencies and percentages. For quantitative data, the researcher used structured and an open ended questionnaire and a composition writing test with learners. The use of both qualitative and quantitative methods of data collection helped determine the extent of use of pedagogical techniques that promote extensive reading habits and also the possible influence of extensive reading on composition writing.

\section{Target Population and Sample Sizes}

The target population for this study was secondary school students and teachers in Laikipia County. The target population was 2670 students in form 2 and 3, 120 English language teachers and 67 secondary school principals. Form 2 and 3 were chosen because these were classes which had settled down and familiarized themselves with reading materials like class readers. They were also thought to have wider experiences in reading yet they were not examination classes. It is also at form 2 that extensive reading of literary and non- literary text is taught according to KIE (2002). In Laikipia County there are 67 secondary schools; among them are 4 boys' schools, 6 girls' and 57 co-educational schools.

\section{Instrumentation}

Data collection instruments were questionnaires, paper test or interview guides. The questionnaire was administered to students to gather data on factors that influence learners' extensive reading habits. The questionnaire also gathered data on extensive reading patterns and preferences amongst secondary school learners. In total (99\%) 327 questionnaires were responded to with only $3(1 \%)$ registering a non-response. The interview guide was administered to English language teachers to gather data on pedagogical techniques that bolster extensive reading habits. The interview guide also tried to gather data on how extensive reading was conducted in their schools and the challenges encountered during teaching. This information was corroborated with data available in English language teachers' professional documents that they use for teaching such as lesson plans and schemes of work.

\section{Research Results and Discussion}

The documents analysis guide attempted to gather data from analysis of documents that teachers used during their teaching of extensive reading skills as it was an important part of the study data. Documents analysis guide makes it possible to corroborate information from the interviews (Yin, 2003). Data from professional documents revealed progress of English reading lessons especially from the lesson plans and schemes of work which are made on a daily basis and yearly respectively. In addition, the documents are expected to have information that cannot be obtained from the interviews and observations (Yin 2003). Pedagogical techniques on reading are important to learners as they provide good opportunities for enquiry and language study including vocabulary, word and text 
structure and spelling patterns that emerge from authentic reading experiences (Makenzi 2009). Table 1 on application of pre-reading techniques shows various techniques that teachers use to prepare learners before actual reading.

Table 1: Use of Pre-reading Skills

\begin{tabular}{|c|c|c|c|c|c|c|c|c|}
\hline $\begin{array}{l}\text { Category } \\
\text { Of } \\
\text { Schools }\end{array}$ & $\begin{array}{l}\text { Percentage of } \\
\text { school }\end{array}$ & $\begin{array}{l}\text { Analysis } \\
\text { of the title } \\
\text { and the } \\
\text { blurb }\end{array}$ & $\begin{array}{l}\text { Skimming } \\
\text { to identify } \\
\text { the theme }\end{array}$ & $\begin{array}{l}\text { Determination } \\
\text { of text } \\
\text { difficulty }\end{array}$ & $\begin{array}{l}\text { Analysis of } \\
\text { topic and } \\
\text { clincher } \\
\text { sentences }\end{array}$ & $\begin{array}{l}\text { Generation } \\
\text { of critical } \\
\text { questions }\end{array}$ & $\begin{array}{l}\text { Discussion } \\
\text { of the topic }\end{array}$ & $\begin{array}{l}\text { Activation } \\
\text { of prior } \\
\text { knowledge }\end{array}$ \\
\hline \multirow[t]{3}{*}{ National } & Count & 4 & 3 & 2 & 3 & 4 & 3 & 2 \\
\hline & $\% \quad$ within & $100 \%$ & $75 \%$ & $50 \%$ & $75 \%$ & $100 \%$ & $75 \%$ & $50 \%$ \\
\hline & $\begin{array}{l}\text { school } \\
\text { category\% of } \\
\text { total }\end{array}$ & $13.3 \%$ & $10 \%$ & $6.7 \%$ & $10 \%$ & $13.3 \%$ & $10 \%$ & $6.7 \%$ \\
\hline \multirow[t]{3}{*}{ County } & Count & 7 & 5 & 6 & 4 & 3 & 4 & 3 \\
\hline & $\% \quad$ within & $70 \%$ & $50 \%$ & $60 \%$ & $40 \%$ & $30 \%$ & $40 \%$ & $30 \%$ \\
\hline & $\begin{array}{l}\text { school } \\
\text { category } \% \text { of } \\
\text { total }\end{array}$ & $23.3 \%$ & $16.7 \%$ & $20 \%$ & $13,3 \%$ & $10 \%$ & $13.3 \%$ & $10 \%$ \\
\hline Sub- & Count & 12 & 8 & 7 & 6 & 4 & 5 & 3 \\
\hline \multirow[t]{2}{*}{ county } & within school & $75 \%$ & $50 \%$ & $43.8 \%$ & $37.5 \%$ & $25 \%$ & $31.2 \%$ & $18.8 \%$ \\
\hline & $\begin{array}{l}\text { category } \% \text { of } \\
\text { total }\end{array}$ & $40 \%$ & $26.7 \%$ & $23.3 \%$ & $20 \%$ & $13.3 \%$ & $16.7 \%$ & $10 \%$ \\
\hline
\end{tabular}

The findings of the study as shown in Table 1 indicate that teachers in all the three categories of schools reported that they used pre-reading techniques to assist the learners align their minds to what they are about to read. The percentage of schools involved was calculated within their individual category (within school) of schools and out of the overall number of schools (category percentage of total) in general. All 4 (100\%) of English language teachers in national schools reported that they assisted learners to analyze the title of the book in terms of literal and symbolic meaning of the title. This coupled with information provided by the author in the blurb gave insights on what the main theme of the text was all about. Recommendations by various readers written by other authorities in the blurb also gave learners direction the book was likely to take in terms of complication of the plot.

Seven $(70 \%)$ of teachers in county schools reported that they assisted learners to analyze the text while 12 $(75 \%)$ of teachers in sub-county school were in agreement on the benefits of title and blurb analysis. Teachers agreed that some titles of books are written to give learners appetite to read. A teacher in a county school said, "Take a title of a play like Betrayal in the City by Francis Imbuga. The learners' curiosity will come out from the content words "betrayal" and "city" and it is from these words that the reader will generate questions like who is betraying who? how? why? why in the city? Who gains or is punished for this vice." Information on recommendation of a book by re-known authors or authorities found at the blurb also provided invaluable information that helped the reader to make informed decision on whether to read the book or not to confirm or reject those assertions.

Another pre-reading technique that teachers reported to be using at pre-reading stage was skimming. This technique involves perusing through a text to get the gist of what the text is all about. A reader could skim through the table of content to get a clue of what the text addresses in terms of themes. A reader may also skim through the topic and clincher sentences in various paragraphs at random to establish major concerns of the text. A third $(75 \%)$ of national school teachers, half $(50 \%)$ of county school teachers and a similar $(50 \%)$ of teachers in subcounty schools taught learners how to skim a text as a very important pre-reading technique.

Data was also obtained that teachers under study also reported using prediction of the text events as a prereading techniques. From the analysis of the theme of the text the learners were taught how to predict the outcome of the text in relation to the past experiences. Very few $(6.7 \%)$ were teachers in national schools and some $(20 \%)$ in county schools. About a quarter $(23.3 \%$ of teachers in sub-county school also taught learners prediction as a pre-reading technique. In total $15(50 \%)$ of the teachers were using this technique.

Teachers also reported that they taught learners how to determine text difficulty as a pre-reading technique so as to avoid time wastage in struggling with a text that was not within their linguistic abilities. Teachers noted that difficult texts in terms of language use and syntax frustrated learners as they struggled to comprehend what was beyond their abilities. This made learners become disinterested in future reading engagement. It was observed that it was important for the language teachers to assist learners determine whether the text was for their level or not. Language teachers observed that if a learner opened pages of a book at random and came across more than ten unfamiliar words and complex sentence structures then there were high chances that the text was not for his level and as such it would distract the reader and slow the pace of reading. Text for reading for enjoyment was supposed to have words that learners did not have difficulty in inferring the meaning and as such they did not stop to use a dictionary to check for the meaning.

Two (50\%) of teachers in national schools, some $6(60 \%)$ of teachers in county schools and few $7(43.8 \%)$ in sub-county schools used determining of text difficult technique at the pre-reading stage. The implication of this 
that learners got time to have an overview of the text and this prepared them on how to approach the text and avoid time wastage. This is supported by Steinhofer (1996) who opines that pre-reading techniques are very important as they help language learners avoid the common tendency of reading a text directly from the start to the end and instead get time to familiarize with the text layout.

Another pre-reading technique reported to be used by English language teachers was learners' generation of critical questions about the main theme or topic of the text. Over a third $11(36.6 \%)$ of the teachers said that they taught the technique. This comprised of all $4(100 \%)$ of national school teachers, nearly a third $3(30 \%)$ of county school teachers and a quarter $4(25 \%)$ of sub-county school teachers. It is clear from the findings that more than half $19(63.4 \%)$ of the teachers did not teach this technique. A major implication of this is that learners may fail to enjoy reading texts that require critical evaluation of the text due lack of critical thinking skills. It is therefore prudent for the English language teachers to emphasize teaching of critical reading skills to enable learners tackle challenges that they encounter as a result of inadequate training of application of the skill. This technique assisted learners to generate answers about what they knew about the topic of the text and then relate it with what was in the text. These questions aided learners in comprehension of the text they were reading. This finding agrees with Smith (1995) and who opines that generation of questions by readers help them to rethink about the text they are reading and approach it with an open mind.

Another pre-reading technique that English language teachers reported using at pre-reading stage was activation of the prior knowledge. Two $(50 \%)$ of the teachers in national schools, three $(30 \%)$ in county schools and a small number $3(18.8 \%)$ in sub-county schools taught this technique. The technique involved the teacher highlighting a topic and letting learners discuss what they knew about the topic and then linking the learners' experiences with what the texts they were about to read were all about. The technique appeared to benefit the learners as they were able to activate their minds about the topics they were about to read. This finding concurs with Fahmi (2003) who emphasized the importance of providing EFL students with reading materials familiar with students' schemata. He also outlined some activities to activate students' prior knowledge before reading. These activities include asking the students to predict what is going to be discussed, asking the students to formulate questions before reading, and teaching students how to write summaries after reading.

\section{During Reading Techniques}

The findings of the study revealed several during reading techniques that the teachers reported to be teaching learners to apply while interacting with reading materials during extensive reading sessions to aid comprehension as illustrated in Table 2.

\section{Table 2: Use of During reading Techniques}

\begin{tabular}{|c|c|c|c|c|c|c|c|c|c|}
\hline $\begin{array}{l}\text { Category } \\
\text { Of } \\
\text { Schools }\end{array}$ & $\begin{array}{l}\text { Percentage of } \\
\text { schools }\end{array}$ & $\begin{array}{l}\text { Formation } \\
\text { of mental } \\
\text { images }\end{array}$ & $\begin{array}{l}\text { Inferring } \\
\text { meaning } \\
\text { of words } \\
\text { in } \\
\text { context }\end{array}$ & $\begin{array}{l}\text { Relating } \\
\text { text } \\
\text { with } \\
\text { others }\end{array}$ & $\begin{array}{l}\text { Predicting } \\
\text { outcome } \\
\text { of events }\end{array}$ & $\begin{array}{l}\text { Identifying } \\
\text { major } \\
\text { issues }\end{array}$ & $\begin{array}{l}\text { Paired } \\
\text { Discussion }\end{array}$ & $\begin{array}{l}\text { Reading } \\
\text { words in } \\
\text { clusters }\end{array}$ & $\begin{array}{l}\text { Plot } \\
\text { direction }\end{array}$ \\
\hline \multirow{3}{*}{ National } & Count & 3 & 4 & 2 & 4 & 2 & 3 & 3 & 4 \\
\hline & $\% \quad$ within & $75 \%$ & $100 \%$ & $50 \%$ & $100 \%$ & $50 \%$ & $75 \%$ & $75 \%$ & $100 \%$ \\
\hline & $\begin{array}{l}\text { school } \\
\text { category } \% \text { of } \\
\text { total }\end{array}$ & $10 \%$ & $13.3 \%$ & $6.7 \%$ & $13.3 \%$ & $6.7 \%$ & $10 \%$ & $10 \%$ & $13.3 \%$ \\
\hline \multirow[t]{3}{*}{ County } & Count & 7 & 7 & 6 & 3 & 4 & 4 & 3 & 8 \\
\hline & $\% \quad$ within & $70 \%$ & $70 \%$ & $60 \%$ & $30 \%$ & $40 \%$ & $40 \%$ & $30 \%$ & $80 \%$ \\
\hline & $\begin{array}{l}\text { school } \\
\text { category } \% \text { of } \\
\text { total }\end{array}$ & $23.3 \%$ & $23.3 \%$ & $20 \%$ & $10 \%$ & $13.3 \%$ & $13.3 \%$ & $10 \%$ & $26.7 \%$ \\
\hline Sub- & Count $\quad \%$ & 8 & 8 & 7 & 3 & 4 & 5 & 4 & 6 \\
\hline \multirow{2}{*}{ county } & within school & $50 \%$ & $50 \%$ & $43.8 \%$ & $18.8 \%$ & $25 \%$ & $31.2 \%$ & $25 \%$ & $37.5 \%$ \\
\hline & category $\%$ of & $26.7 \%$ & $26.7 \%$ & $23.3 \%$ & $10 \%$ & $13.3 \%$ & $16.7 \%$ & $13.3 \%$ & $20 \%$ \\
\hline
\end{tabular}

From the study findings as indicated in Table 2, The percentage of schools involved was calculated within their individual category (within school) of schools and out of the overall number of schools (category percentage of total) in general. More than half $18(60 \%)$ of the teachers reported to have taught learners on how to apply formation of mental images or visualize as a while reading technique. These comprised of three (75\%) of teachers in national schools, seven (70\%) in county schools and eight (50\%) in sub-county schools. The technique involved the learners being encouraged to visualize what they read and letting characters of the books they read interact in their mind. These mental images helped the reader to see the conflict and understand the plot of the text. This finding agrees with the findings in the United states of America of National Reading Panel (2000) that established that visualization helps learners construct images of what they read and so English language teachers should endeavour to assist and motivate learners visualize settings, characters and events and ask them to write or draw what comes to their mind once they visualize. The implication of this finding is that learners who cannot visualize what they are reading by letting characters interact in their mind may have difficulties trying to comprehend what 
they are reading. This may also cause challenges in their engagement in extensive reading. It is therefore important for the English language teacher to teachers on how to create mental scenes so as to enliven character interaction in their mind and thus ease comprehension of what they are reading.

Another technique reported to have been used by teachers was assisting learners to infer the meanings of words in context. Through inferring students would be able to draw conclusions, make predictions, identify underlying themes, use information to create meaning from text, and use pictures to create meaning (Harvey \& Goudvis, 2000). Learners can keenly look at illustrations, graphs, pictures, dates, related vocabulary and titles from the text to make inferences. The teachers were of the view that learners stopping to check the meanings of words in dictionary should be discouraged as they would reduce the reading speed and distract them from the storyline. More than half $(63.3 \%)$ of teachers used this technique. It comprised of four (100\%) in national schools, seven $(70 \%)$ in county schools and eight $(50 \%)$ in sub-county schools. Teachers agreed that the problem in inferring meanings of words may be compounded by learner's inadequate vocabulary, lexical inefficiency, structural complexity and language inaccessibility. The learners should be in a position to understand the context in which the word has been used. They should also be in a position to dissect a word into prefix, root or base and suffix in order to try to understand it. These finding agrees with Davis (1995) who opines that words having different syntactical functions and varieties of inflectional endings may also cause difficulties for the learners in reading a text effectively.

These findings on reading methods also corroborate with the findings of a study in Taiwan, Tseng (1996) who studied the relationship between reading comprehension and reading methods and learning styles of EFL 12th grade male students. Tseng (1996) found that most students could benefit from both silent and oral reading activities. Tseng suggests that EFL teachers should be more flexible in selecting various reading methods for use in the classroom setting. Teachers could support a mixture of oral and silent reading assignments that would allow students to engage in their preferred style while reading independently.

The findings of the study also established that teachers also taught prediction of outcome of events as a while reading technique. Fourteen $(48.3 \%$ ) of English language teachers interviewed taught prediction of outcome as during reading technique to their learners. This comprised of four $(100 \%)$ of teachers in national schools, three $(30 \%)$ in county schools and three $(18.8 \%)$ is sub-county schools. Prediction of outcome of events in the text assisted the learner in interacting with the events and characters in the text and this aided in the comprehension of the text. The reader is able to predict an outcome of an event and be motivated to continue reading to establish whether the prediction was correct or not. This is in agreement with Irvin, Meltzer and Dukes (2015) who observe that students should learn to generate good questions in reference to their extensive reading endeavours. Questioning is effective for improving comprehension because it provides students with a purpose for reading, focuses attention on what must be learned, helps develop active thinking while reading, helps monitor comprehension, reviews content, and relates what is being learned to what is already known.

Another while reading technique that teachers taught was identifying major issues, themes or concerns of the text or reading materials. Nearly half $(45 \%)$ of the teachers reported to have taught learners how to identify major themes of the text. This comprised of $2(50 \%)$ of teachers in national schools, four $(40 \%)$ in county schools and a quarter $(25 \%)$ of teachers in sub-county schools. Identifying of major themes assisted the learners to follow the story line. This also helped to understand the point of views of the writer and also what motivated the actions of the characters.

The findings of the study also established that teachers taught learners to read words in clusters instead of reading word by word. This increased their reading speed and aided comprehension. Nearly half (45\%) of the teachers reported to have taught this technique as a while reading technique. This comprised of $3(75 \%)$ of teachers in national schools, three $(30 \%)$ of teachers in county schools and four $(25 \%)$ of teachers in sub-county schools. Another while reading technique teachers reported to have taught was following the plot or the story line of the text. The learners were taught to establish how events in a text unfolded chronologically. A majority $(77.5 \%)$ of the teachers reported to have taught this technique. This comprised of $4(100 \%)$ of the teachers in national schools, $8(80 \%)$ in county schools and $6(37.5 \%)$ in sub-county schools. These results agree with the perception held by Nuttall (1996) that learners need to be equipped with techniques that they can apply while reading so that when comprehension breaks down they can be able to repair and move on reading. The findings of the study also established that learners were also taught post reading techniques to help the practice what they had read or internalize concepts learnt after interacting with reading materials. The post reading techniques taught to the learners are shown on Table 3. 
Table 3: Post reading Techniques

\begin{tabular}{|c|c|c|c|c|c|c|c|c|c|}
\hline $\begin{array}{l}\text { Category } \\
\text { Of Schools }\end{array}$ & $\begin{array}{l}\text { Percentage of } \\
\text { schools }\end{array}$ & Retelling & $\begin{array}{l}\text { Writing } \\
\text { summary }\end{array}$ & $\begin{array}{l}\text { Writing } \\
\text { composition }\end{array}$ & $\begin{array}{l}\text { Writing } \\
\text { diaries }\end{array}$ & $\begin{array}{l}\text { Writing } \\
\text { book } \\
\text { reviews }\end{array}$ & $\begin{array}{l}\text { Group } \\
\text { discussion }\end{array}$ & $\begin{array}{l}\text { Writing } \\
\text { posters }\end{array}$ & $\begin{array}{l}\text { Leaving } \\
\text { a note } \\
\text { on the } \\
\text { text }\end{array}$ \\
\hline \multirow[t]{3}{*}{ National } & Count & 2 & 3 & 4 & 2 & 2 & 3 & 3 & 2 \\
\hline & $\%$ within school & $50 \%$ & $75 \%$ & $100 \%$ & $50 \%$ & $50 \%$ & $75 \%$ & $75 \%$ & $50 \%$ \\
\hline & $\begin{array}{l}\text { category } \% \text { of } \\
\text { total }\end{array}$ & $6.7 \%$ & $10 \%$ & $13.3 \%$ & $6.7 \%$ & $6.7 \%$ & $10 \%$ & $10 \%$ & $6.7 \%$ \\
\hline \multirow[t]{3}{*}{ County } & Count & 8 & 7 & 5 & 3 & 4 & 7 & 3 & 8 \\
\hline & $\%$ within school & $80 \%$ & $70 \%$ & $50 \%$ & $30 \%$ & $40 \%$ & $70 \%$ & $30 \%$ & $80 \%$ \\
\hline & $\begin{array}{l}\text { category } \% \text { of } \\
\text { total }\end{array}$ & $26.7 \%$ & $23.3 \%$ & $16.7 \%$ & $10 \%$ & $13.3 \%$ & $23.3 \%$ & $10 \%$ & $26.7 \%$ \\
\hline \multirow[t]{3}{*}{ Sub-county } & Count $\%$ within & 7 & 6 & 7 & 4 & 3 & 5 & 6 & 4 \\
\hline & school & $43.8 \%$ & $37.5 \%$ & $43.8 \%$ & $25 \%$ & $18.8 \%$ & $31.2 \%$ & $37.5 \%$ & $25 \%$ \\
\hline & $\begin{array}{lll}\text { category } & \% \text { of } \\
\text { total } & & \end{array}$ & $23.3 \%$ & $20 \%$ & $23.3 \%$ & $13.3 \%$ & $10 \%$ & $16.7 \%$ & $20 \%$ & $13.3 \%$ \\
\hline
\end{tabular}

From the study data indicated in Table 3, retelling of what a learner had read in classroom was one of the post reading technique teachers reported to have used. This narration had other benefits of mastery of oral skills as well as instilling confidence in speech. Two $(50 \%)$ of national schools teachers, eight $(80 \%)$ of county schools teachers and seven $(43.8 \%)$ of sub-county school teachers applied this post reading technique in the course of their teaching. This technique helped learners to learn from one another and also served as an avenue of revealing interesting reading materials to other learners.

Teachers also asked learners to write brief summaries of what they had read during reading lessons. This enabled the teacher to have a track of what the learners were reading and also sharpening their writing skills. More than half $(53 \%)$ of the teachers reported that they applied this post reading technique. This comprised of $3(75 \%)$ of the teachers in national schools, $7(70 \%)$ in county schools and $6(37.5 \%)$ of teachers in sub-county schools. Teachers reported that the summaries learners wrote had a bearing on reading interests and gave insights on the kind of books and other reading materials that were on high demand in their schools. This also sharpened their writing skills.

Language teachers also generated composition writing tasks from themes that learners had read about after discussions as a post reading activities. Teachers collected themes from learners during reading lessons and then on the basis of those themes gave guided compositions to test their comprehension and writing skills. More than half $(53.3 \%)$ of the teachers reported to have used this post-reading technique.

Another post reading technique teachers reported to have taught was diary entry. This involved learners making diary entries on what they were reading on daily or weekly bases. Learners were encouraged to develop vocabulary journal in the diary where they wrote unfamiliar words they encountered while reading. Diary entries helped learners to keep individual track on what they were reading and enable them to remain focused on reading tasks. This self-monitoring encouraged learners to take charge of their own reading. Less than a third $(30 \%)$ of the teachers reported teaching learners how to apply diary entries as a post reading technique. This comprised of 2 $(50 \%)$ of the English language teachers in national schools, $3(30 \%)$ in county schools and $4(25 \%)$ in sub-county schools.

Another post reading technique that teachers reported teaching was asking learners writing book reviews. These book reviews are synopsis of a text highlighting the main conflict, plot and characters in the text. The book reviews also have resolution of the conflict and further recommendations for reading. These books reviews were then pinned on the class notice boards to motivate learners to read. The book review writers would also write their name for easier access of the book. Only less than a third (30\%) used this post reading technique. This consisted of $2(50 \%)$ of English language teachers in national schools, $4(40 \%)$ in county schools and $3(18.8 \%)$. Therefore majority $(70 \%)$ of the teachers did not view writing book reviews as an important post reading technique. Those teachers who applied the technique reported that it was beneficial to the learners as it helped improve their writing skills. This implies that those learners who were not taught writing book reviews as a post reading technique were missing an important component in language learning.

The findings of the study also established that half (50\%) of the teachers reported to have taught how to carry out critical discussions on what the learners had read. This was comprised of $3(75 \%)$ in national schools, $7(70 \%)$ in county schools and $5(31.2 \%)$ in sub-county schools. The learners were placed in small groups and each given an opportunity to inform other about what he was reading and whether it was of interest to him or not. The groups would then be dismantled and the learners redistributed to other groups to ensure they reaped maximum benefits from the discussions. This technique not only did it encourage the learners to read in extensive reading programmes but also boosted their self-esteem and confidence as a result of participation in group sharing activity.

The study findings also established almost half $(46.7 \%)$ of the teachers reported that they had books fixed with a blank paper after the cover page where learners wrote personal comments on their feelings about the text. 
These comments guided each subsequent reader in making their decisions on whether to read the book or not and also what to expect while reading. Definitely positive comments would motivate a reader to read the text. This technique was applied by half $(50 \%)$ of teachers in national schools, more than three quarters $(80 \%)$ in county schools and a quarter $(25 \%)$ in sub-county schools.

\section{Conclusions}

This study investigated the pedagogical techniques that bolster learners' extensive reading habits. The findings were that teachers possessed pedagogic knowledge for teaching reading skills but this was not reflected very well in the learners as many claimed that they still encountered difficulties in the course of the their reading. From the discussion of the key findings, this study has made conclusions as follows. Based on the finding that English language teacher possessed adequate pedagogic knowledge and skills on teaching of reading, it is therefore logical to conclude that English language teachers are equipped with adequate reading techniques required to assist the learners engage in extensive reading with ease. So English language teachers should closely monitor what learners are reading and offer remedial assistance where challenges are encountered.

\section{References}

Commeyras, M. \& Mazile, M.B, (2011). Exploring the culture of reading among primary school teachers in Botswana. The reading teacher, 64 (6), 418-28.

Davis, C. (1995). Extensive Reading: An expensive extravagance? ELT Journal,49 (4), 329336.

DeForge,J.(2012)Retrievedfromhttp://blog.leeandlow.com/2012/07/23/goal-setting-for-reading-success-part-1setting-a-reachable-standards-aligned-reading-goal/

Fahmi, A. 2003, August. Activating learner long-term memory in teaching EFL reading. Paper presented at the Network of University English Service Providers (NUESP) conference, Jember.

Fraenkel,J.R. \& Wallen, N,E.,(2003). How to Design \& Evaluate Research in Education. New York: McGrawHill High Education.

Gicobi, M. (2013, 1, October). Exam Audit Report Lays Bare Serious Language Problems. Daily Nation, p. 10.

Harvey, S., \& Goudvis, A. (2000). Strategies that work teaching comprehension to enhance understanding. York, ME: Stenhouse Publishers.

Ikerege, V. N. (2013, May 26). Why Kenyan youth are unable to take up the reading culture. The Sunday Nation, Nairobi: .p.14.

Irvin, J. L., Meltzer, J., \& Dukes, M. S. (2015).Taking Action on Adolescent literacy. Student Motivation, Engagement and Achievement. Retrieved June 28, 2015 from http:///www.ascd.org/publications/books/107034/chapters/students/Engagement and Achievement.aspx.

Kenya National Examination Council. (2014). Kenya certificate of secondary examination English report . Nairobi, Kenya: Government Printers.

Kenya Institute of Education (ed) (2002). Secondary education syllabus volume 5 (rev.ed. ). Nairobi:Kenya Literature Bureau.

Kenya National Examination Council (2012-2013). Regulations for the Kenya Certificate of Secondary Examinations 2012-2013. Nairobi: KNEC.

Kombo, D. K. \& Tromp, D.L.A. (2009). Proposal and Thesis writing: An introduction. Makuyu, Kenya: Don Bosco printing press.

Makenzi, M. (2009). Reading out to the less advantaged. Reading Tents in Kenya. World Library Information congress. Paper presented in $70^{\text {th }}$ IFLA General Conference, Beunos AIRES, Argentina. Abstract retrieved from http:www.ifla.org/i.

Mugenda, A.G. \& Mugenda, M. O (1999). Research Methods; Quantitative and Qualitative Approaches. Nairobi: Acts Press.

National Reading Panel. (2000). Comprehension III teacher preparation and comprehension strategies instruction. (Chap.4). Retrieved from http://www.nichd.nih.gov/publications/nrplch4-111.pdf.

Ngwiri, M. (2014, 8, March). Why General Command of English among Youth has gone to the Dogs Daily Nation, p.12.

Nuttall, C. (1996). Teaching reading skills in a foreign language ( $2^{\text {nd }}$ ed.). Oxford: Macmillan Heinemann.

Orodho, K.A. (2005). Elements of Educational and Social Science Research Methods. Nairobi: Masola Publishers.

Rosenburg, D. (Ed) (2003). Reader development and reading promotion: recent experiences from seven countries in Africa. Oxford: International Network for the availability of scientific.

Rumelhart, D. E. (1980). Toward an interactive model of reading. In S. Dornic (ed.), Attention and Performance IV. New York, NY: Academic Press.

Schunk,D.(2009).Goal setting. $\quad$ Retrieved from $\quad$ Education http://www.education.com/reference/article/goal-setting/ 
Sentuwa, R.(2004). The role of children's reading Tent in the promotion of the reading culture in Uganda. (Unpublished dissertation), Makerere University, Rubega Division. Reading engagement: Motivating readers through integrated instruction (pp.34-50). Newark, DE: International Reading Association.

Shiundu, J.S. \& Omulando, S.J. (1992). Curriculum: Theory and practice in Kenya. Nairobi: Oxford University Press.

Smith, B.E (1995).Seeking Breadth and Depth in Reading Comprehension. New York: Doubleday.

Steinhofer, H. (1996). How to read nonfictional English texts faster and more effectively. The Internet TESL Journal, 2 (6), 1996.

Tseng, Y. (1996). The Relationship of reading methods and learning styles to Taiwanese 12th Grade male students' reading comprehension in English. A Dissertation presented to The Faculty of the School of Education International and Multicultural Education Department.

West, M. \& Schwerdt, G.(2012).The middle school plunge. Education Next,7(4),63-68.

Yin, R. K. (2003). Case study research design and methods. London: Sage Publication.

\section{Recommendations}

1. English language teachers should ensure that reading instruction is presented in a structured manner during reading time

2.The Ministry of Education should develop a mechanism of monitoring reading trends of learners in schools with the aim of ensuring that all learners meet the minimum threshold of linguistic competences to engage in extensive reading in schools

3.The Kenya Institute of Curriculum Development (KICD), the body responsible for development of curriculum materials, in collaboration with schools should come up with a strong extensive reading policy and more time should be allocated for reading in schools.

\section{Areas for Further Research}

1. A comparative study of extensive reading habits between learners in private and public secondary schools.

2. The impact of language teachers reading pedagogic knowledge on development of learners' reading interest in secondary schools..

3. The influence of extensive reading habits on secondary schools learners' oral communication skills. 